\title{
Cold and World War II: Understanding the Causes, Views and Conceptual Analysis
}

\author{
Abraham Kuol Nyuon \\ A/Prof of Politics, Peace and Security, University of Juba
}

\begin{abstract}
This article examines the theoretical framework of the cold war as the basis for comprehending the genesis of the Cold War. This author gave emphasizes to events which clearly elaborate the end of the war known as the superpowers struggle from 1945-1991 by focusing on factors which have speed up the collapse of the Cold War resulting into the new World Order. In this paper, the author argued that, the Cold War and World War II are inseparable because conflict among the Allies surfaced at the end of the World War II. This paper set out how World War II shaped the beginning of the Cold War through engaging with the major schools of thoughts that are considered as the cause of Cold War. Therefore, the blame for the escalation of the Cold war should be attributed to both the United States and the Soviet Union as both of them were serving their national interest.
\end{abstract}

Key words: War, interest, power, ideology, determinants, cessation, orthodox, revisionist, realist, War, destruction, assured, mutually, weapon and competition.

\section{INTRODUCTION}

\section{An overview}

The Cold War is often inferred in terms of a skirmish between good and evil, with the Soviet Union being depicted as an "evil empire" that challenged the United States the mighty giant or good one because of being the leader of the Western world. As John Lukacs explained, "Stalin, not Roosevelt, was the principal architect of the iron curtain of the cold war due to major ideological-political differences as the central question, and in the end, as the main cause of Cold War confrontation (John Lukacs,:1961，P. 65). The ideological differences, material capabilities, security interests and contrasting personalities of those in power, it was no wonder that any possibility of cooperation between Moscow and Washington vanished after the common objective of defeating the Axis powers had been achieved. This article is about the end of Cold War emphasizing the main factors which have contributed to the termination of the Cold War. It should be comprehended that the end Cold War was a multifarious event with back-and-forth factors involved over a decade.

\section{Determinants of the End of the Cold War}

This essay focuses on the main factors which have played a major in speeding up the end of the Cold War. This section emphasize factors or events which clearly elaborate the end of the Cold war known as the superpowers struggle from 1945-1991 but will focus on factors which have speed up the collapse of the Cold War such as Economic Decline, Insolvency of Communist Ideology, Paradigm shift and idiosyncratic variable. The factors examined in this paper include.

\subsection{The economic decline.}

The first factor to examine is the economic decline; the role of economic decline in ending the cold war is well explained by Suri when he says, the Soviet Union's foreign policy was oriented toward Defence during the Cold War which made the economy to decline badly in 1970s 
because the power of Soviet's economy was determine by its extend of overpowering those of Western Countries with huge budget on Defence which enabled the Soviet Union to lost her credibility of the economic ability to sustained Cold with the West leading to the economic sluggishness from 1970s and 1980s (Suri, J :2002, Pp.78-79). Suri was echoed by Brown by outlining the rational of economy during the Cold War such as lagging in the industrial investment, obsoleteness of technology, collapse of various utilities, deterioration of different infrastructures and lack of energy, thus, the Soviet Union was willing to open up her economies to western countries (Brown, A :1996, Pp.98-99). This was followed by reformation from Eastern countries such as Hungary, Poland and Soviet Union toward a free market-oriented policy (Gaddis, J.L: 2005, p.293).

Gorbachev knew very well that his country cannot compete with United States in term of Defence budget spending which enabled him to come up with reform agenda of Perestroika and Glasnost. This imminent economic decline leads to what I called Insolvency of Communist Ideology in this paper which is the second factor in the end of the Cold War.

\subsection{The Communist ideology}

The second factor to explore is the insolvency of Communist ideology; this factor has a greatest rationale for the cessation of Cold War because the communist blocs lost their prestige the philosophy of Communism and its tenets making her supporters reluctant to support this dysfunctional ideology as stated by Zavisca that, the Soviet leadership led by Gorbachev came to realization that the entire system of Communism is defunct and could not compete with the Western ideology of capitalism making the west to win ideologically, thus, the west gave more pressure on the Soviet Union making them to win the Cold War through strong, weakness, thus become vulnerable to external compressions (Fairbank, C :1993,
Pp. 46-56). While Kegley says that the conceptual heritages of Communism surprise death are credited to myriad of factors such as its economy and acceptable ideology (Zavisca, J.R: 2011, p.929). Fairbank further this argument by saying that, the dysfunction of Communist ideology made the United States strategy to be successful in putting an end to communism by referring the ideology of communism as a nature of beast established within itself that create internal ability to against the nature of human spirit, successive revolts which referring it as "the revolt of the soul against the soullessness of Communism (Kegley, C.W:1994, P.12).

\subsection{The cessation of Cold War}

The third factor to examine in this essay on the cessation of Cold War is the Paradigm shift Kegley and Gaddis have elaborated this section better by stating that the notion of new thinking emerged on the $27^{\text {th }}$ Party convention which was conducted in January 1986. Young and Kent explore the assumption for the resolution as the availability of the weapons of mass destruction which enabled the security and defence issue to be a political task which could be dealt with through political avenues, hence, the relations between United States and the Soviet Union should be built on mutuality and cooperation which bring about a great shift in Soviet philosophy of foreign policy (Young,J and Kent, J :2004, P.579).

The idea of new thinking and its contribution to the end of Cold War was based on the honesty and togetherness of the humanity in Soviet Policy. Thus, the Soviets become who they are, not through their personal character but through relations with other societies in the international system (Mustafa, A: 1997, Pp.282-300). This concept helps to end the Cold War because the leaders of both the Soviet Union and the United States of America were convinced that collaboration and affinity was the only solution to the long-time deadlock of the Cold War. 


\subsection{The personality of Gorbachev and Reagan.}

The fourth factor is the personality of Gorbachev and Reagan, the idiosyncratic variable of two leaders in ending the Cold war was clearly explained by Matlock in his book entitled Autopsy on an Empire when he says that, the Reagan concept of the security defence initiative (SDI) made the Soviet Union to be on her knees by prompting Gorbachev leadership to be submissive to the Western power by accepting the independence of the Eastern Europe countries and began to reduce the arms as a signal of ending the Cold War (Matlock, J.F :1995, Pp.75-77).

The author was convinced with assertion of Zubok who stated that, Cold war came to an end because of the personality and power of Gorbachev and the leader of the Soviet Union. According to Zubok Gorbachev introduced two policies which change a lot of things in the Soviet government. First, he relinquished the function of the party by transferring the economic control from the party to the State and secondly, he orders for the quick and immediate implantation of the new policy (Zubok, V.M: 2007, Pp.303-304). The role played by the leaders of the superpowers involved in the Cold war in the end of Cold War is evidenced. Reagan was a hardliner with anti-communist regime which made him to work hard to influence his country's public opinion and that of the western countries to overcome Communism. Gorbachev and those who supported his ideas in his government look upto the West as partners to realize international peace through arm control and restriction on arm proliferation to enhance appropriate environment for human living. Crockatt support the essence of two leaders in the ending Cold War by saying that, they legitimized their reforms through political concessions by their opponents. According to Crockatt, the concept of Perestroika and Glasnost enabled the people of the United Soviet Socialist Republic to start to undermine the authoritarian regimes
(Croakat, R: 1995, Pp.338-340). As the society undermine the Communist system, this led to the collapse of Communism prompting a surprise end to the Cold War.

\section{The an inevitable outcome of World War II?}

The Cold War and World War II are inseparable because conflict among the Allies surfaced at the end of the World War II. The Cold War was a product of World War II in many ways, most apparently as presented by the ideological differences express by the former allies as well as the concept of deterrence by the United States and Soviet Union with their respective allies. This paper set out how World War II shaped the beginning of the Cold War through engaging with the major schools of thoughts that are considered as the cause of Cold War.

\subsection{The Orthodox view}

The first is the Orthodox view that emerged in the 1950s and 1960s. It is a product of a society heavily influenced by the breakdown of the wartime alliance and the expansion of Soviet power in Europe, the loss of China to Communism and the Korean War. This school of thought argued that it was Soviet aggression in Eastern Europe and other parts of the world that had caused the Cold War. Hence, the United States had no choice but to meet the challenges posed by the Soviets. This perspective was focused on the idea that if the blame is to be attributed for the outbreak of the Cold War, the Soviet Union deserves to be credited with full responsibility for the onset of conflict while the United States is purely naive. This view expresses that, Soviet fierceness in its leadership and the entire system of the government should be blame for the escalation of the Cold war. This view is exemplified by Herbert Feis works which argues that, "The Russian people were trying to extend their boundaries and takeover the neighbouring countries through revolution by breaking the coalition (Feis,: 1957, P.655). Thus, Feis 
applies the concept of the level of analysis in understanding the origin of Cold War by emphasizing the idiosyncratic variable and the systematic approach to international relations. In similar comportment, Gaddis affirms that, in the countenance of the Soviet fortitude to embark upon the policy of expansion, the United States had to protect its legitimacy, interest and democracy among the European Union (Gaddis,: 1965, p.11). Moreover, Arthur echoed them by saying that, the Cold War was the courageous and essential response of Communist aggression (Schlesinger: 1967, p.51). Thus, Arthur and others in this school of thought have focused on attributing the blame or responsibility for the Cold War by arguing that, the Soviet Union was responsible for the escalation of the Cold War.

\subsection{The Revisionist view}

The second major school of thought on the matter is the Revisionist view which surfaced in the 1960s when new generations of historians were disillusioned by the Vietnam War and appalled by seemingly endemic government dishonesty. According to this view, The United States had been primarily responsible for Cold War and the Soviet Union did not show any aggressive desire toward the West because the United States had used their nuclear monopoly to threaten as well as intimidating Stalin to be aggressive while President Truman had recklessly abandoned the recklessly the more conciliatory policies of Franklin Roosevelt by taking a provocative hard line against the Russia. This view was supported by Lloyd Gardner's argument that, the United States, which was the strongest nation at a time, ought to have shown more understanding of Moscow's essential economic and security interest because the United States at the end of World War II had greater opportunity to influence the international situation than the Soviet Union whose condition in victory was worse in many ways than those of defeated countries (Gardner, :1970, p.317).

\subsection{The Post-revisionist school}

The third major view explaining the reasons for the Cold War is the Postrevisionist school. This school of thought is the middle ground of both the Orthodox and Revisionist view. It tries to show that both sides had their faults and that over time both superpowers pushed their own interests and misunderstood the other side even to the point of leading to the possibility of nuclear war. The post-revisionists have tended to accept the revisionists' view that Stalin was more concerned with Soviet security and to that end the creation of a Soviet sphere of influence in Eastern and Central Europe with world aggressive ambitions towards Western Europe; but at the same time they have argued that Western leaders could not be certain of what Stalin was actually trying to achieve because what Stalin perceived to be security was often interpreted a threaten to the interests of the United States and other Western states allied to her (Jerald, :1983, p.232). However despite accepting that there were problems on both sides, a number of the post-revisionists have become highly critical of the Soviet Union. John Lewis Gaddis, one of the leading historians in this area, has engaged in what could best be described as a post revisionist interpretation especially since the collapse of the Soviet Union and the opening up of Soviet archives (Norman, :1962, p.129). This view asserts that, the Cold War was caused by the conflicting interests of the United States and the Soviet Union compounded by miscommunication and poor diplomacy. The differences in the cultures of the United States political leaders and their morals as well as righteous justifications for diplomacy from Soviet leaders' Communist expansionist policies led to the disentanglement of the new international order nearly established in Roosevelt's wartime conferences with Churchill and Stalin (Adam,: 1974, Pp.334336). This school of thought also explains that the Cold War was caused by the social climate and tensions in Europe at the end of World War II and by the increasing power 
struggles between the Soviet Union and the United States (Young \& Kent, :2004, p.45) . Economic separation between the Soviets and the West also heightened tensions along with the threat of nuclear war (Fursenko \& Naftali, :1997, pp. 166-170.).

\subsection{The Realist school of thought}

A fourth key view on this question is the Realist school of thought, this view states that, World War II, polarized the world resulting in a Cold War between two superpowers, the United States and the Soviet Union )Kegley, :2007, p.115). The concept of deterrence is an essential view which had contributed to escalation of Cold War in conjunction with the above schools of thoughts. The use of military threats as a means to deter international crises and war has been a central topic of international security during the entire period of Cold war. A threat serves as a deterrent to the extent that it convinces its target not to carry out the intended action because of the costs and losses that target would incur. Deterrence theory gained increased prominence as a military strategy during the Cold War with regard to the use of nuclear weapons by taking on a unique connotation during this time as an inferior nuclear force through virtue of its extreme destructive power to deter a more powerful adversary (Towle, :2000, P.164). According to Huth, a policy of deterrence can fit into two broad categories being preventing an armed attack against a state's own territory or preventing an armed attack against another state (Huth.:1999, p.25-40). Deterrence theory holds that nuclear weapons are intended to deter other states from attacking with their nuclear weapons through the promise of retaliation and possibly mutually assured destruction (MAD). The fear of the great powers in destroying each other through Nuclear Weapons lead to a War which cold spare them from destruction known as Cold war.

\section{CONCLUSION}

In Conclusion, despite the abovementioned factors leading to the end of the Cold War, Gaddis summarized the reason for the cessation of Cold War as military, ideological, cultural, economic insufficiency, and deficiency of the moral within the Soviet Union. The author strongly agreed that the Soviet Economic crisis lead to the insolvency of communist ideology brought which brought about the new thinking within the Communist blocs and lastly, the role of Gorbachev and Reagan cannot be underestimated because without the two leaders, the policies which speed up the cessation of Cold War could have not been achieved. All the factors discussed in this paper have contributed to the end of Cold War were an initiative of the leaders themselves, there one much in putting to end the Cold War between the United States of America and the Soviet Union.

Moreover, on the role of World War II in the escalation of the Cold War, First, the political environment was marked by competition to win new adherents to one or the other economic and social system. Both sides maintained empires, as John Lewis Gaddis noted that, in Europe, the United States led an empire by invitation while the Soviet Union ruled an empire by imposition (Gaddis,: 1997, pp 284-286). The Second, the principal locus of United States and Soviet conflict underwent a geographic shift from one region to another as nations committed themselves to one camp or the other. The Third, economic production and technological advance was a key instrument in United States and Soviet competition because direct economic competition between the superpowers underwrote the expansion of influence around the world which demonstrated the superiority of an economic system. Therefore, the blame for the escalation of the Cold war should be attributed to both the United States and the Soviet Union as both of them where serving their national interest. Thus, post-revisionist position is the best option in explaining the 
origin of the Cold War because it blames the two superpowers at end of Cold War by emphasizing the spirit of dominance. The United States promotes Capitalism while the Soviet Union promotes Communism and each of these ideologies protected through the concept of deterrence for accentuating national interest.

Acknowledgement: None

\section{Conflict of Interest: None}

\section{Source of Funding: None}

\section{REFERENCES}

1. Adam, Ulam (1974), Expansion and Coexistence, New York: Praeger.

2. Aleksander. F\& Timothy .N (1998), "One Hell of A gamble: The secret History of the Cuban missile Crisis, New York: W.W Norton \& Company Inc.

3. Arthur, Schlesinger (1967), The Origin of Cold War in Foreign Affairs, Vol 46, October

4. Brown, A (1996), Gorbachev Factor, Oxford: Oxford University Press Croakat, R (1995), Fifty Years War: The United States and Soviet Union in World Politics,

London:Routledge,Publication

Fairbank, C (1993), The Nature of the Best: The national interest, Vol.31, spring, Pp. 46-56

5. Charles, Kegley (2007), World Politics: Trends and Transformation, Belmont: Thomson.

6. Gaddis, J.L (2005), The Cold War: A new History, New York: Penguin Press, p.293 Kegley, C.W (1994), How Did the Cold War Die? Principles for an Autopsy, Vol.38. No.1, Aprill, pp.11-41.

7. Gaddis, John Lewis (1997), We Now Know: Rethinking Cold War History, Oxford and New York: Oxford University Press.

8. Gaddis, Smith (1965), American Diplomacy during the second World War 1941-1945, New York: Willey.
9. Herbert, Feis (1957), ChurchilRoosevelt-Stalin. The War they waged and Peace they sought, Princeton: Princeton University Press.

10. Huth, P. K. (1999), Deterrence and International Conflict: Empirical Findings and Theoretical Debate, Annual Review of Political Science, pp. 25-48.

11. Jerald, Combs (1983), American Diplomatic History: Two Centuries of Changing Interpretation, Berkeley: University of California Press.

12. John L. Gaddis, (1983), The Emerging Post-Revisionists synthesis on the Origin of Cold War in the Diplomatic History, Vol 7, No 3,

13. John Lukacs, (1961), A History of the Cold War, New York: Doubleday \& Company, Inc.

14. John Young \& John Kent (2004), International Relations since 1945: A global History, Oxford: Oxford University Press.

15. Lloyd, Gardner (1970), Architect of Illusion:Man and Ideas in American foreign Policy,1941-1949, Chicago : Quadrangle Books.

16. Matlock, J.F (1995), Autopsy on an Empire: The American Ambassador Account of the collapse of the Soviet Union, New York: Random House.

17. Mustafa, A (1997), Manifesto for A rational Sociology, the American Journal of Sociology, Vol.103, No.2 September, Pp.282-300.

18. Norman, Graebner (1962), Cold War Diplomacy, 1945-1960, New York: D. Von Nostrand.

19. Suri, J (2002), Explaining the End of Cold War: A new Historical Consensus, Vol.4, No.4, Pp.78-79.

20. Towle, Philip (2000), "Cold War", In Charles Townshend. The Oxford History of Modern War, New York: Oxford University Press.

21. Young,J and Kent, J (2004), International Relations Since 1945, Oxford: Oxford University Press, 
22. Zavisca, J.R (2011), Explaining and Interpreting the End of Cold War, Vol.12, No.4.p.929.

23. Zubok, V.M (2007), A failed Empire: The Soviet Union in the Cold War from Stalin to Gorbachev, Chapel Hill: University of North Carolina Press.
How to cite this article: Nyuon AK. Cold and world war II: understanding the causes, views and conceptual analysis. International Journal of Research and Review. 2021; 8(4): 408-414. DOI: https://doi.org/ 10.52403/ijrr.20210448 